\title{
Changes in the Pattern of Protein Synthesis During the First Three Hours of Sporulation in Bacillus subtilis
}

\author{
By M. D. YUDKIN,${ }^{1 *}+$ HASSIA BOSCHWITZ, ${ }^{1}$ YAHLI LORCH ${ }^{2}$ \\ AND A. KEYNAN ${ }^{1}$ \\ ${ }^{1}$ Laboratory of Developmental and Molecular Biology, Department of Biological Chemistry, \\ ${ }^{2}$ Department of Genetics, Institute of Life Sciences, Hebrew University of Jerusalem, Givat-Ram, \\ Jerusalem, Israel
}

(Received 30 November 1981; revised 22 January 1982)

\begin{abstract}
Cultures were labelled with $\mathrm{L}-\left[{ }^{35} S\right]$ methionine for 5 min periods immediately after resuspension in sporulation medium $\left(t_{0}\right)$ or at hourly intervals thereafter $\left(t_{1}, t_{2}\right.$ or $\left.t_{3}\right)$. Cells were harvested and lysed very rapidly at low temperature in the presence of inhibitors of protease, cell extracts were subjected to high-resolution two-dimensional gel electrophoresis, and radioactive proteins were revealed by fluorography. Comparisons of fluorograms from wild-type cells labelled at various times after resuspension showed that 35 proteins were synthesized at $t_{1}$ that were not seen at $t_{0}$, ten at $t_{2}$ that were not seen at $t_{1}$, and seven at $t_{3}$ that were not seen at $t_{2}$. Conversely, nine proteins ceased to be synthesized in the first hour of resuspension, eight in the second hour and five in the third hour. Experiments with the same protocol were done with cells of a strain carrying spo-43, a mutation that blocks sporulation at a very early stage. The results show that the mutation prevents about two-thirds of the total number of changes that occur in the wildtype in the first hour, about one-third of those that occur in the second hour, but only two out of 12 of those that occur in the third hour.
\end{abstract}

\section{INTRODUCTION}

Sporulation in Bacillus subtilis is under the control of specific genes, whose number amounts to at least several dozen (Piggot \& Coote, 1976). However, very little is known about the function of the individual genes, and in no case has the product of a sporulation-specific gene been unequivocally identified.

In the hope of arriving at a more complete description of the biochemical changes that occur in sporulation and, in the long run, of assigning sporulation-specific proteins to the genes that encode them, we have begun to study protein synthesis in sporulating cultures by two-dimensional gel electrophoresis. Linn \& Losick (1976) used this technique to show that the pattern of protein synthesis in cells during the fourth hour of sporulation differed from the pattern in vegetative cells. In this paper we describe the sequence of changes that occur as cells progress from the moment of resuspension in sporulation medium to a point three hours later. We also describe the effect of a very early sporulation-specific mutation on this sequence.

\section{METHODS}

Materials. Ampholines were from LKB. Deoxyribonuclease I (pancreatic, chromatographically purified), ribonuclease A (pancreatic, $5 \times$ crystallized) and lysozyme (Grade I) were from Sigma. 2-Mercaptoethanol and urea were from Bio-Rad as were acrylamide and the other materials necessary for gel electrophoresis. EDTA was neutralized with $\mathrm{NaOH}$. L- $\left[{ }^{35} \mathrm{~S}\right]$ Methionine $\left[>1000 \mathrm{Ci}(37 \mathrm{TBq}) \mathrm{mmol}^{-1}\right]$ was from Amersham. U.K.

$\dagger$ Present address: Microbiology Unit, Department of Biochemistry, South Parks Road, Oxford OX13QU, 
Organisms. Bacillus subtilis strain MY2002 (his A lys-l pyrD1 rfm) is $\mathrm{Spo}^{+}$and is here referred to as the wild-type. Strain MY2000.43 (lys-I pyrDI rfm spoOA43) was constructed by using strain 43.4 (spoOA43 leu-8) (from J. Mandelstam) to transform MY2002 to $\mathrm{His}^{+}$by the technique of Ephrati-Elizur (1968) and obtaining a spo recombinant by congression; a back-cross established that the spo marker was identical to that in strain 43.4 .

Growth and resuspension. Cultures were grown at $37^{\circ} \mathrm{C}$ with vigorous shaking in a medium containing $\left(\mathrm{g} \mathrm{l}^{-1}\right)$ : $\mathrm{KH}_{2} \mathrm{PO}_{4}, 2 ; \mathrm{NH}_{4} \mathrm{Cl}, 0.535 ; \mathrm{Na}_{2} \mathrm{SO}_{4} ; 0 \cdot 107 ; \mathrm{MgSO}_{4} .7 \mathrm{H}_{2} \mathrm{O}, 0.099 ; \mathrm{NH}_{4} \mathrm{NO}_{3}, 0.096 ; \mathrm{MnSO}_{4} .4 \mathrm{H}_{2} \mathrm{O}, 0.022 ;$ $\mathrm{CaCl}_{2}, 0.02 ; \mathrm{FeCl}_{3} .6 \mathrm{H}_{2} \mathrm{O}, 0.001 ; \mathrm{L}$-glutamic acid mono-sodium salt, 4.24 ; L-asparagine, 2 ; L-alanine, $0.125 ; \mathrm{L}-$ arginine, L-aspartic acid, L-glutamine, glycine, L-histidine, L-isoleucine, L-leucine, L-lysine, L-phenylalanine, Lserine, L-threonine, L-tyrosine, L-valine, 0.025 each; L-cystine, 0.02; L-tryptophan 0.02 ; uracil 0.01 ; yeast extract (Difco), 0.01 ; adjusted with $\mathrm{NaOH}$ to $\mathrm{pH} 7 \cdot 0$. Under these conditions the mean doubling time was 50 to $55 \mathrm{~min}$. When the turbidity at $600 \mathrm{~nm}$ reached 0.75 , a portion of the culture was transferred with a warm pipette to a warm centrifuge tube, and the cells were collected by centrifugation for $4 \mathrm{~min}$ at maximum speed $\left(6000 \mathrm{rev}\right.$. $\left.\mathrm{min}^{-1}\right)$ in a bench-top centrifuge. The pellet was resuspended in twice the original volume of pre-warmed resuspension medium (Sterlini \& Mandelstam, 1969), supplemented with growth medium (1\%, v/v) and with L-histidine $\left(25 \mathrm{mg} \mathrm{l}^{-1}\right)$, L-lysine $\left(25 \mathrm{mg} \mathrm{l}^{-1}\right)$, uracil $\left(10 \mathrm{mg} \mathrm{l}^{-1}\right)$ and yeast extract $\left(10 \mathrm{mg} \mathrm{l}^{-1}\right)$ and adjusted to $\mathrm{pH} 7 \cdot 0$. The culture was shaken vigorously at $37^{\circ} \mathrm{C}$; in the wild-type 70 to $90 \%$ of the cells contained pre-spores $8 \mathrm{~h}$ after resuspension. Times (in $\mathrm{h}$ ) after resuspension are referred to as $t_{1}, t_{2}$, etc.

Labelling and preparation of cell extracts. A $1 \mathrm{ml}$ portion of the culture was added from a warm pipette to a warm flask containing $20 \mu \mathrm{Ci}$ of $\mathrm{L}-\left[{ }^{35} S\right]$ methionine and $10 \mathrm{ng}$ of non-radioactive L-methionine in a total volume of $40 \mu \mathrm{l}$, which was then shaken at $37^{\circ} \mathrm{C}$. After $5 \mathrm{~min}$ (by which time the cells had incorporated no more than $70 \%$ of the radioactivity available to them), the flask was plunged into a mixture of ice and water. A $0.35 \mathrm{ml}$ volume of ice-cold lysozyme solution $\left(7.5 \mathrm{mg} \mathrm{ml}^{-1}\right)$ in $0.4 \mathrm{M}$-EDTA was added, followed by $70 \mu$ phenylmethylsulphonyl fluoride solution $\left(6 \mathrm{mg} \mathrm{ml}^{-1}\right)$ in ethanol. The mixture was quickly transferred to a chilled tube, and the cells were collected by centrifugation for $1 \mathrm{~min}$ at 0 to $4{ }^{\circ} \mathrm{C}$ in an Eppendorf centrifuge model 5412. The supernatant liquid was removed as completely as possible; the pellet was resuspended in $25 \mu 1$ of a solution containing $10 \mathrm{mM}-\mathrm{Tris} / \mathrm{HCl}$, pH 7.4, 10 mm-EDTA, lysozyme $\left(0.5 \mathrm{mg} \mathrm{ml}^{-1}\right)$ and phenylmethylsulphonyl fluoride $\left(5 \%, \mathrm{v} / \mathrm{v}\right.$ of a $6 \mathrm{mg} \mathrm{ml}^{-1}$ solution in ethanol), incubated for $10 \mathrm{~s}$ at $0{ }^{\circ} \mathrm{C}$, frozen in liquid $\mathrm{N}_{2}$ and thawed in a mixture of ice and water. A $5 \mu \mathrm{l}$ volume of a solution of deoxyribonuclease $\left(2 \mathrm{mg} \mathrm{ml}^{-1}\right)$ and ribonuclease $\left(2 \mathrm{mg} \mathrm{ml}^{-1}\right)$ in $0.25 \mathrm{M}-\mathrm{MgCl}_{2}$ was added, and after $10 \mathrm{~s}$ at $0{ }^{\circ} \mathrm{C}$ the reaction was stopped by the addition of $5 \mu 10.4 \mathrm{M}$-EDTA, $30 \mathrm{mg}$ of solid urea and $50 \mu \mathrm{l}$ 'lysis buffer' (O'Farrell, 1975). The mixture was frozen and thawed three times and centrifuged for 2 min at 0 to $4{ }^{\circ} \mathrm{C}$ in an Eppendorf centrifuge. The small pellet was discarded, and the supernatant extract, which contained 80 to $90 \%$ of the radioactivity incorporated by the cells, was stored at $-70^{\circ} \mathrm{C}$ until analysed.

Two-dimensional gel electrophoresis. Samples, containing 15 to $20 \mu \mathrm{g}$ protein, were analysed by the technique of O'Farrell (1975) with the following modifications. The first dimension (isoelectric focusing) gels were $11.5 \mathrm{~cm}$ long and contained Ampholines pH range 3.5 to 9.5 instead of 3 to 10. They were run for $14 \mathrm{~h}$ at $350 \mathrm{~V}$ and then for $1 \mathrm{~h}$ at $800 \mathrm{~V}$. After extrusion from their tubes, the first dimension gels were equilibrated with 'sodium dodecyl sulphate sample buffer' (O'Farrell, 1975) for various lengths of time (see Results) before being loaded on to slab gels. These were $21 \mathrm{~cm}$ long, and contained $11 \%(\mathrm{w} / \mathrm{v})$ acrylamide. After electrophoresis the radioactive protein spots were detected by fluorography (Bonner \& Laskey, 1974) on Kodak XRP-1 film.

\section{RESULTS}

\section{Detection of newly-synthesized proteins during sporulation}

The design of our experiments to study the pattern of protein synthesis during sporulation was as follows (details are given in Methods). Cells were harvested from exponentially growing cultures and resuspended in sporulation medium. Either immediately thereafter $\left(t_{0}\right)$ or at $t_{1}, t_{2}$ or $t_{3}$, a portion of culture was exposed to $\left.{ }^{35} \mathrm{~S}\right]$ methionine for $5 \mathrm{~min}$. The cells were chilled and quickly harvested, and cell extracts were made extremely rapidly at low temperature in the presence of inhibitors of protease (Prestidge et al., 1971). These extracts were then analysed by two-dimensional gel electrophoresis (O'Farrell, 1975).

\section{Exposure of the fluorograms}

Since different proteins are labelled to very different extents during the exposure to radioactive methionine, there is no single time of exposure of the gels to film that is ideal. Short exposures, sufficient to reveal the prominent spots, fail to show proteins that are weakly labelled; long exposures reveal the feebly labelled proteins but cause the heavily labelled spots to spread on the film. We found it best to expose the gels to film twice (at least), once so that the 
product (c.p.m. applied to the gel $\times$ days of exposure) was about $5 \times 10^{5}$, and once so that it was about $2 \times 10^{6}$. A further increase in the length of exposure made the resolution worse but revealed hardly any additional spots. The number of spots that we can detect at present on our fluorograms is about 480 to 500 , which is lower by a factor of two than the number of Escherichia coli proteins detected by O'Farrell (1975); we are seeking improvements in the technique that will increase the number.

\section{Equilibration time}

The technique of O'Farrell (1975) involves electrophoretic separation of proteins in two dimensions. After proteins in the sample have been separated in the first dimension by isoelectric focusing, the resulting disc gel is shaken with an equilibration buffer containing SDS and then applied to the top of a polyacrylamide slab gel for electrophoresis in the second dimension in the presence of SDS. O'Farrell (1975) states that the optimum time for equilibration of the disc gel is $2 \mathrm{~h}$. With $B$. subtilis extracts we found that equilibration for $2 \mathrm{~h}$ caused extensive loss of the low molecular weight proteins; with 45 min equilibration resolution of the low molecular weight proteins was excellent, but the high molecular weight proteins were badly streaked (compare Fig. $1 a$ and $b$ ). On some occasions we got good resolution over the whole area of the gel by using 75 to 90 min equilibration, but we generally found that the most complete picture of the radioactive proteins in a sample was obtained by analysing the sample twice, once with a short and once with a long equilibration.

For illustrating our subsequent results we have chosen fluorograms that show most clearly the protein spots that we wish to discuss.

\section{Concentration of acrylamide in the second dimension}

In an extensive series of preliminary experiments we tried the effect of varying the concentration of acrylamide in the second-dimension gel. We eventually found that $11 \%(\mathrm{w} / \mathrm{v})$ acrylamide gave the most uniform distribution of protein spots. Gradient gels gave no better separation in our system than the single acrylamide concentration of $11 \%$.

\section{Reproducibility of the protein patterns}

Although we were extremely careful to use standard conditions for electrophoretic analyses, the absolute position of the spots on the resulting fluorograms differed slightly from one separation to the next. As a result, it was not possible to align spots over the whole area of the fluorograms in the way that one can align, for instance, replica plates: if corresponding spots were aligned at the top of the two fluorograms they were sometimes 2 to $3 \mathrm{~mm}$ out of alignment at the bottom. However, all the fluorograms that we compared had most of their spots in common (see below), with the result that each area of the film contained a distinctive pattern of spots; we were therefore able to compare each part of the film by aligning these patterns.

We established the reproducibility of the system by making several comparisons of samples taken from different experiments but at the same time after resuspension of the cells in sporulation medium. On every occasion when we compared two samples of wild-type cells labelled at $t_{1}$, more than $97 \%$ of the spots were common to the two fluorograms. Patterns of proteins from cells labelled at $t_{2}$ or at $t_{3}$ were just as reproducible. Patterns obtained from cells at $t_{0}$ (immediately after resuspension) were also equally reproducible, and were indistinguishable from patterns obtained when cells were labelled during exponential growth.

The conclusions presented here are based on studying patterns from five independent experiments with the wild-type and five with strain MY2000.43.

\section{The pattern of protein synthesis in wild-type cells}

Figures 2 to 5 show fluorograms of extracts from cells labelled at $t_{0}, t_{1}, t_{2}$ and $t_{3}$. Detailed study of the fluorograms shown in Figs 2 and 3 , and of several others from cells labelled at $t_{0}$ and $t_{1}$, shows that 35 spots are present at $t_{1}$ that are never seen in cells incubated with [ $\left.{ }^{35} \mathrm{~S}\right] \mathrm{methionine}$ either at $t_{0}$ or during exponential growth. (These are labelled 101 to 135 in Fig. 3.) Similarly, ten 


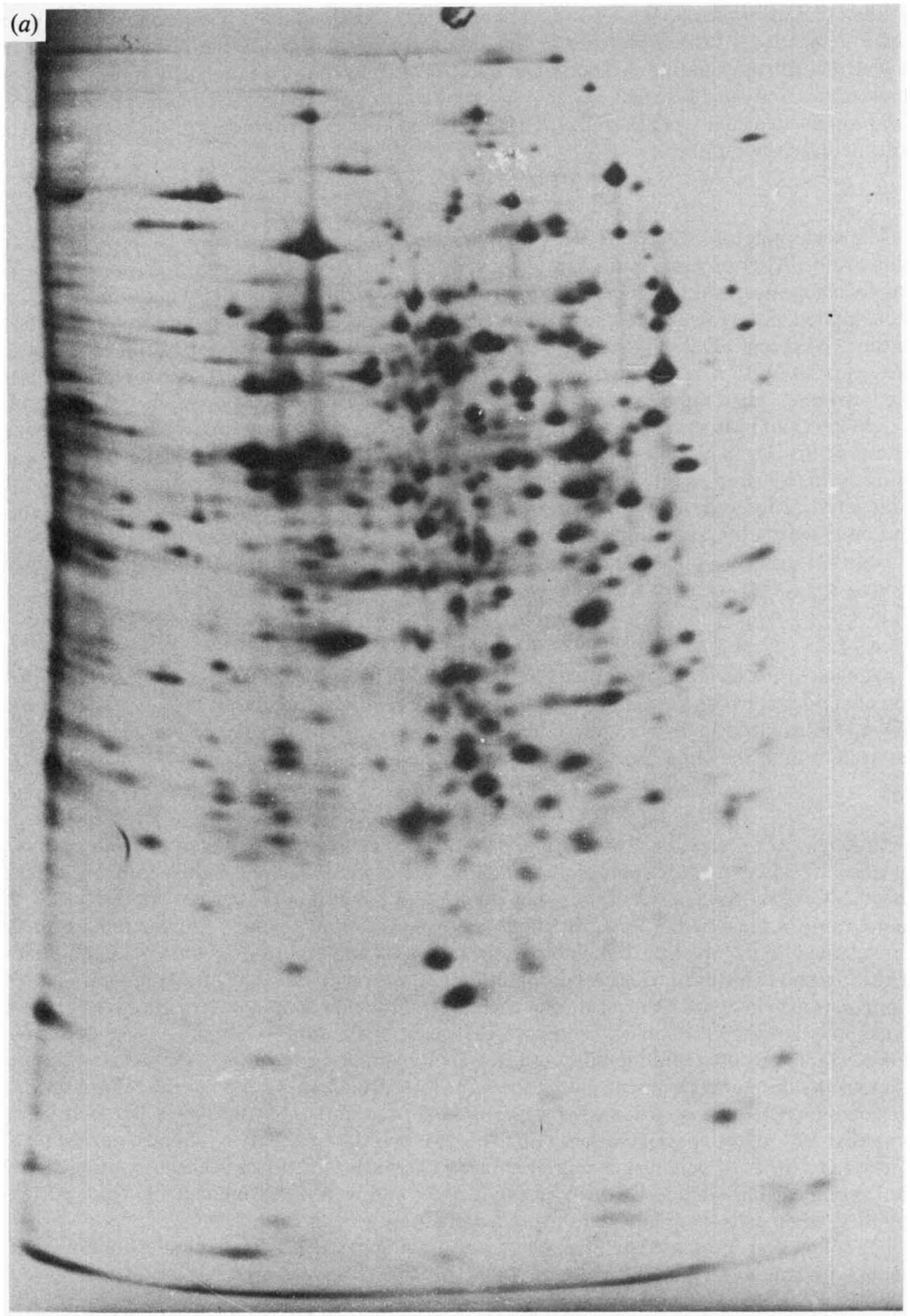

Fig. 1. The effect of equilibration on the pattern of spots obtained in two-dimensional electrophoresis. Extracts made from sporulating wild-type cultures labelled at $t_{3}$ were separated by isoelectric focusing. The resulting disc gels were shaken with equilibration buffer (O'Farrell, 1975) for $(a) 120$ min or (b) 45 min and subjected to SDS-PAGE as described in Methods. The spots were revealed by fluorography. In 
(b)

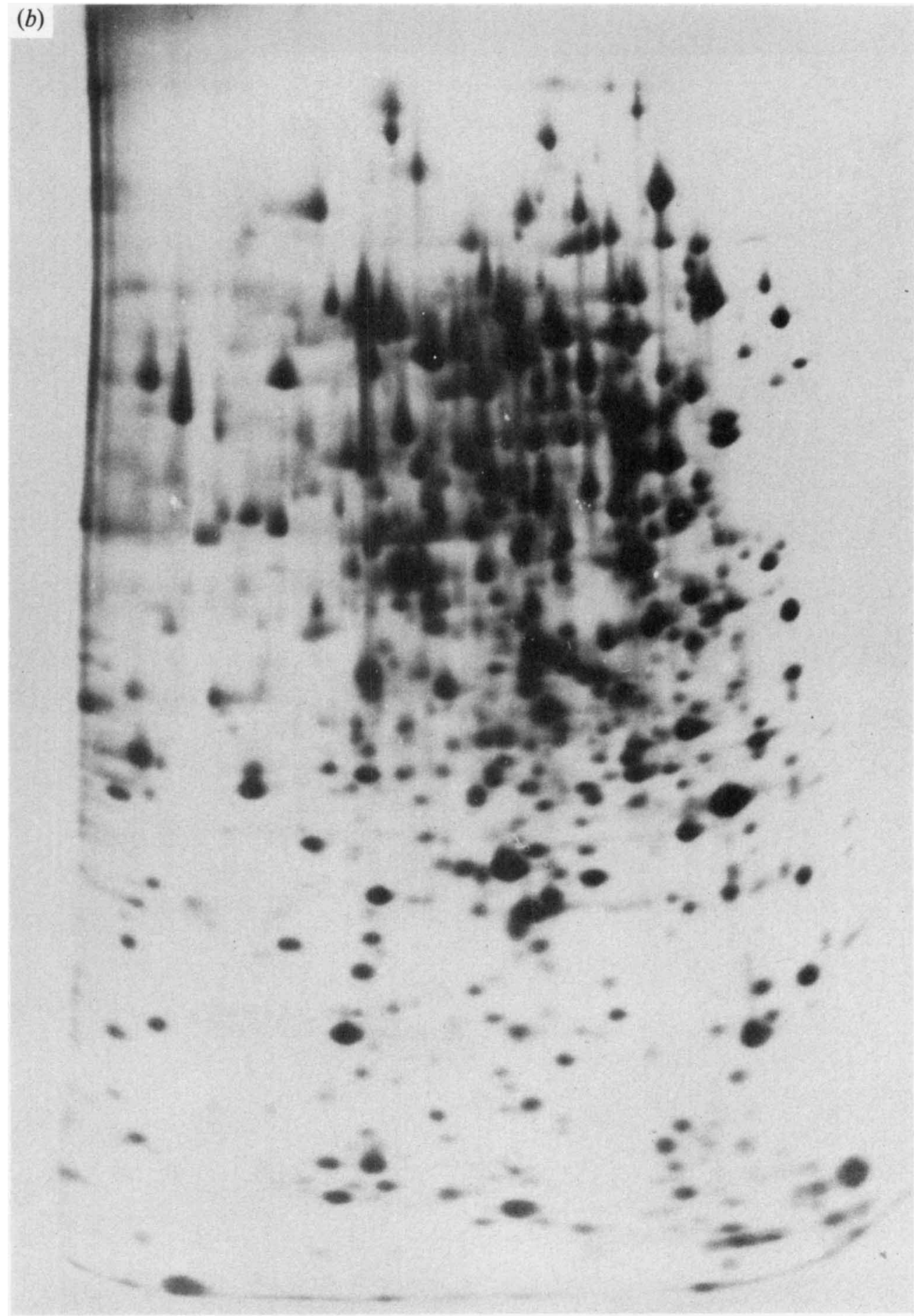

these and the subsequent figures, the horizontal dimension corresponds to the length of the disc gel used for isoelectric focusing, with the more acidic end (approx. $\mathrm{pH} \mathrm{4.8)} \mathrm{being} \mathrm{towards} \mathrm{the} \mathrm{right} \mathrm{and} \mathrm{the} \mathrm{more}$ basic end (approx. $\mathrm{pH} 7.0$ ) towards the left. The vertical dimension corresponds to the length of the slab gel, with the proteins of low molecular weight running near the bottom. 


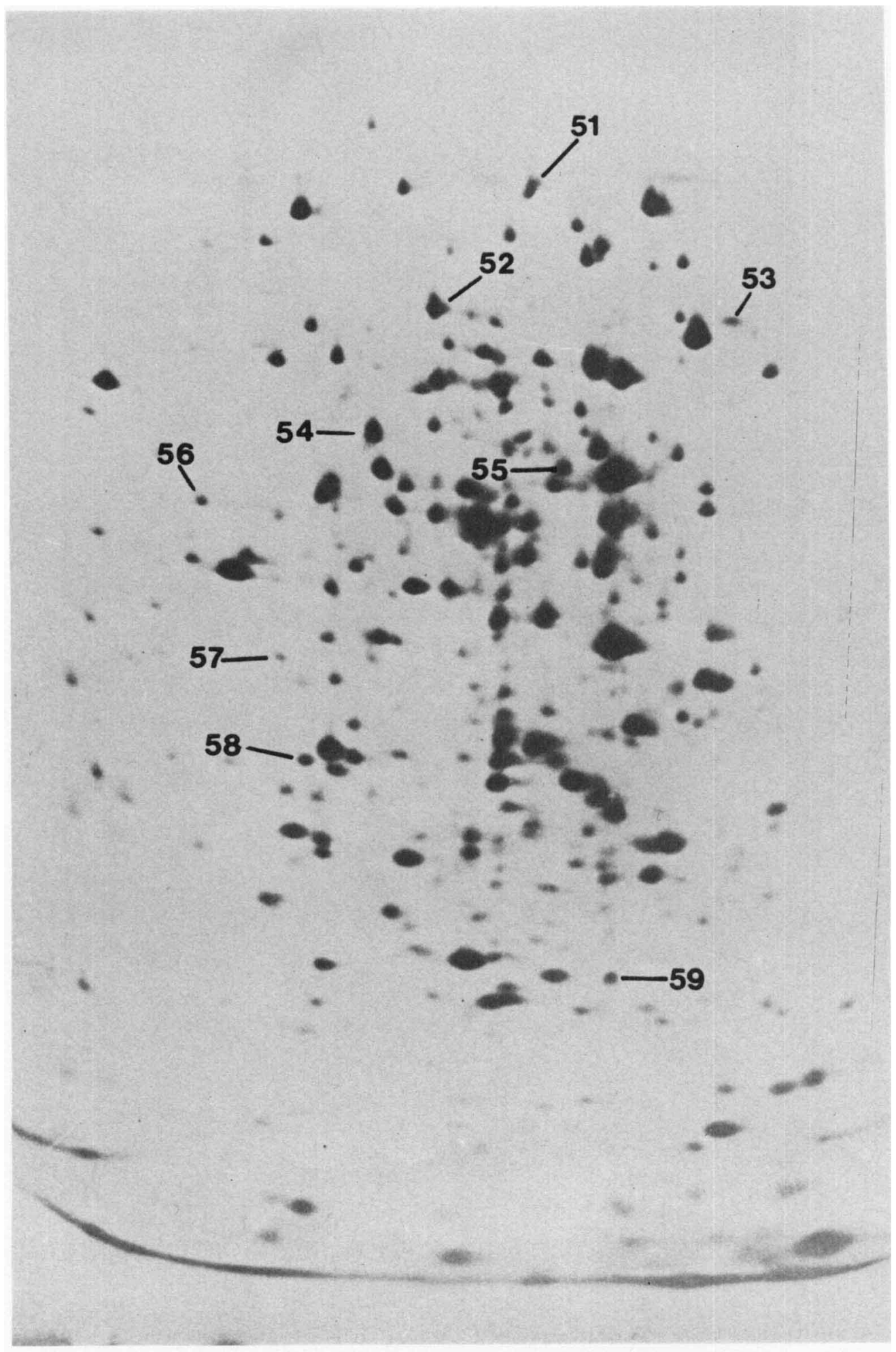

Fig. 2. Fluorogram of a two-dimensional separation of an extract of wild-type cells labelled at $t_{0}$. Equilibration was for $90 \mathrm{~min}$. 


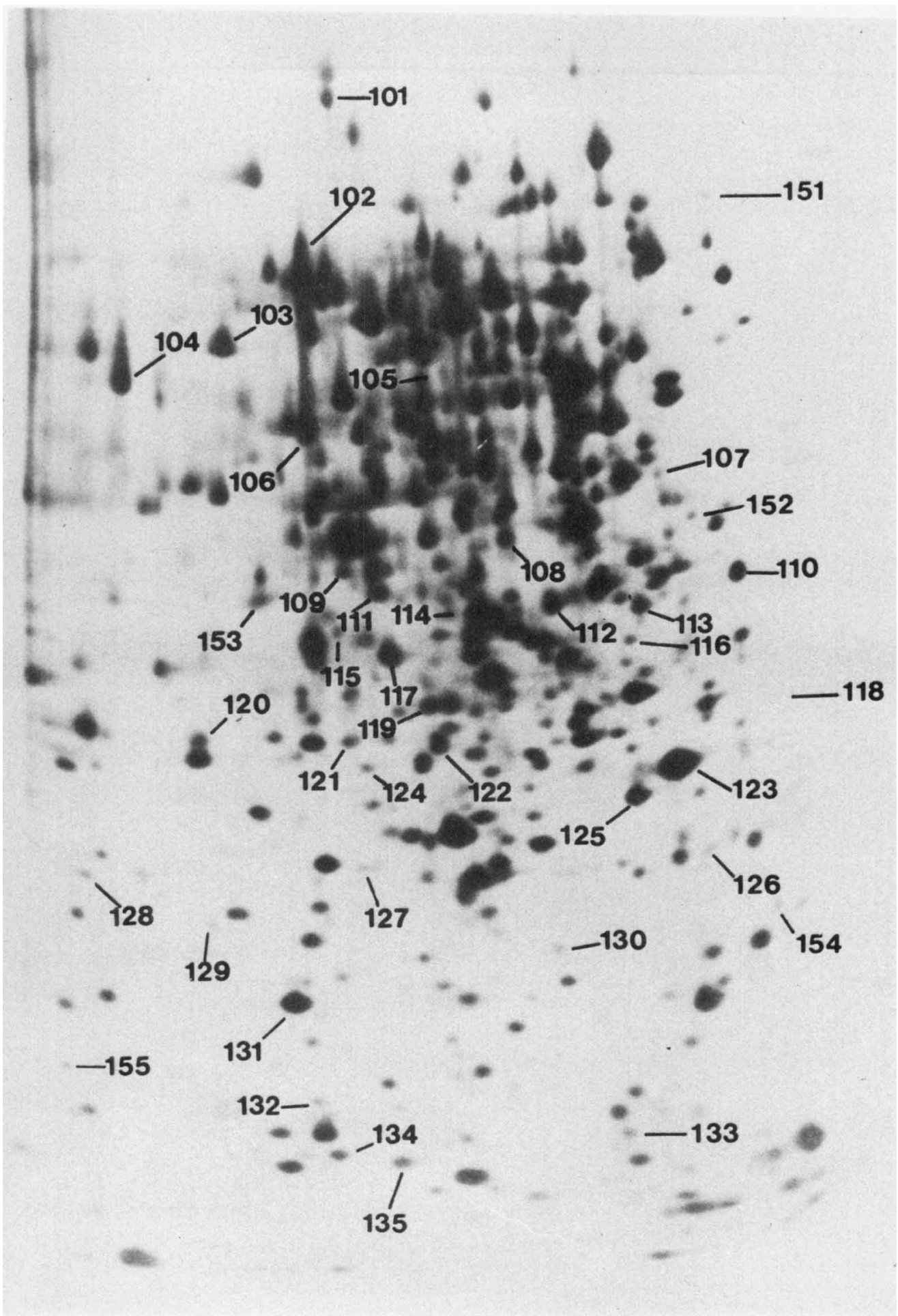

Fig. 3. Fluorogram of a two-dimensional separation of an extract of wild-type cells labelled at $t_{1}$. Equilibration was for $60 \mathrm{~min}$. 


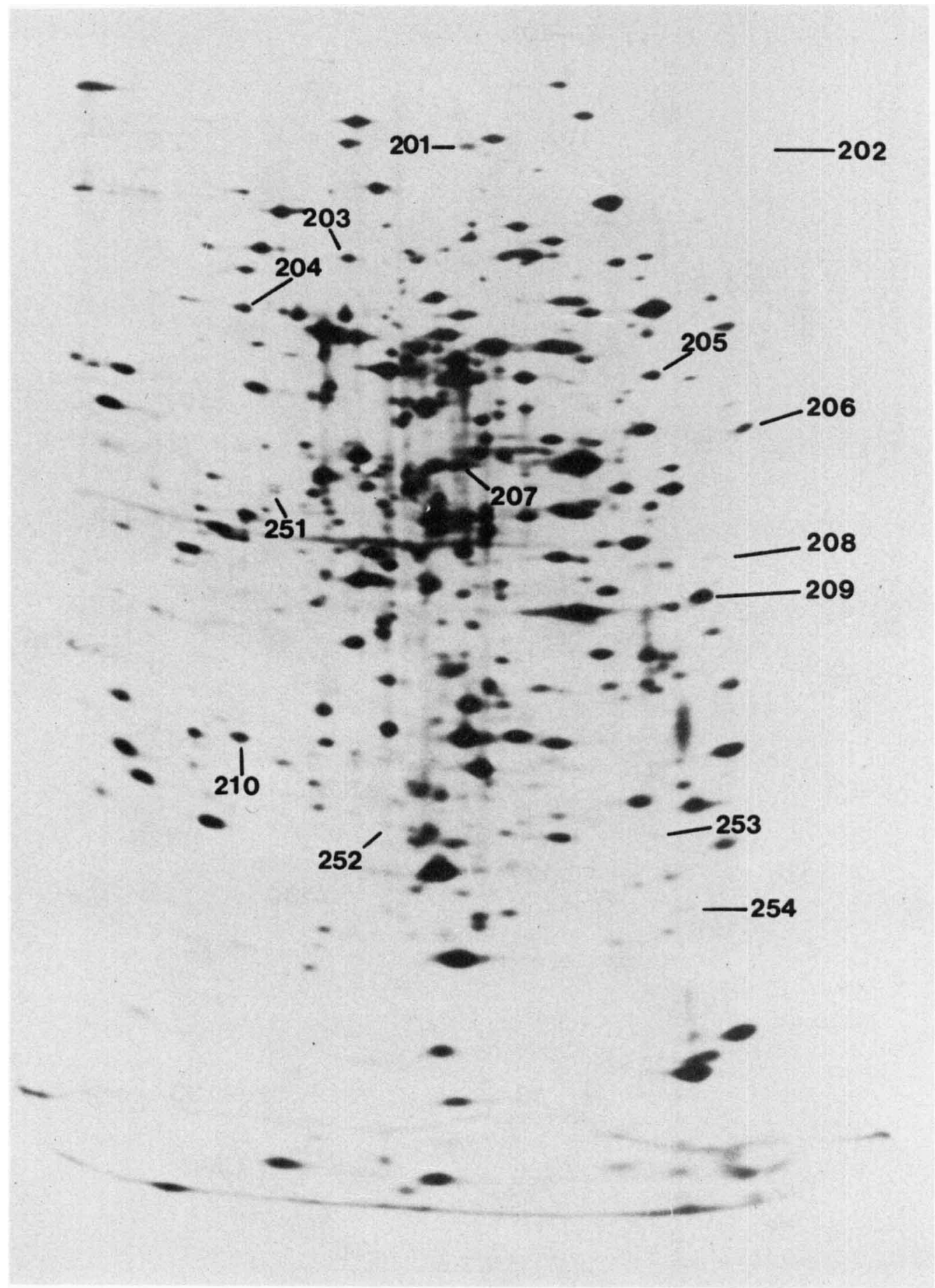

Fig. 4. Fluorogram of a two-dimensional separation of an extract of wild-type cells labelled at $t_{2}$. Equilibration was for $90 \mathrm{~min}$. 


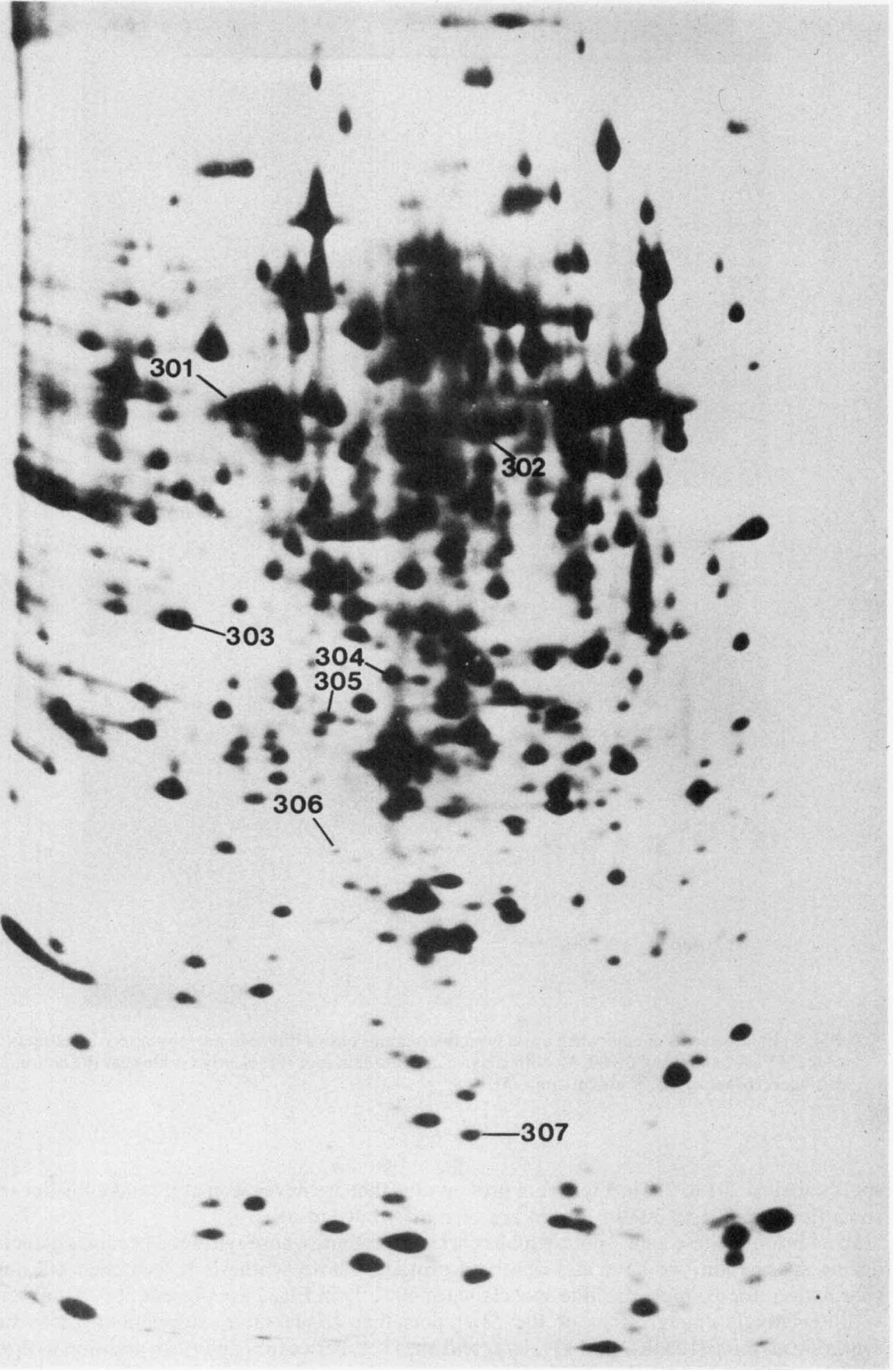

Fig. 5. Fluorogram of a two-dimensional separation of an extract of wild-type cells labelled at $t_{3}$. Equilibration was for $60 \mathrm{~min}$. 


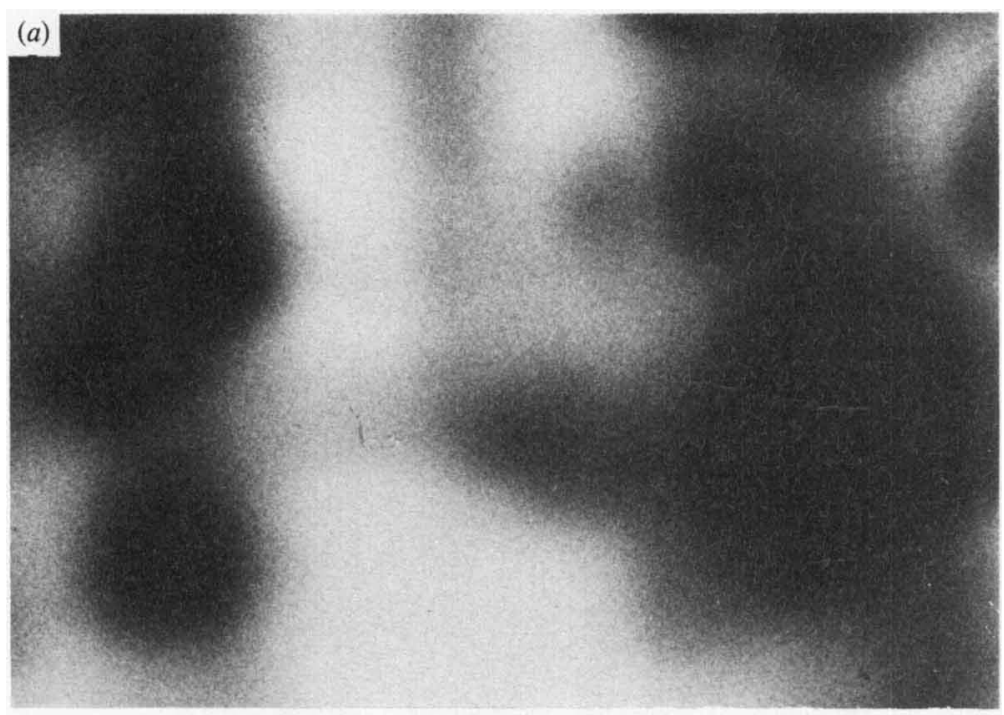

(b)

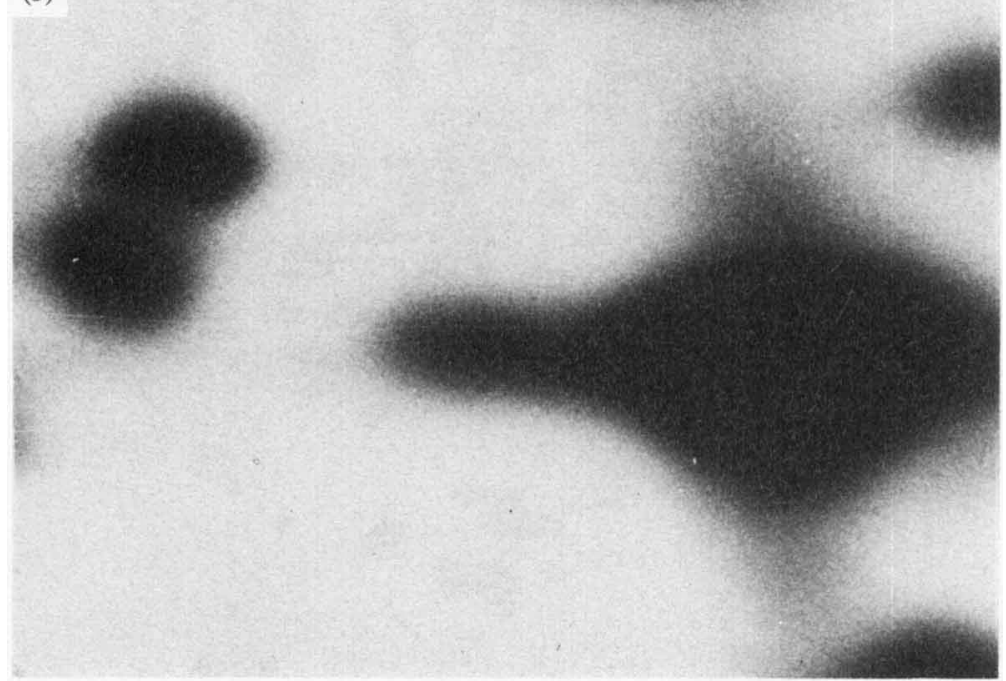

Fig. 6. Enlargements of equivalent areas from fluorograms of two-dimensional separations of extracts of $(a)$ MY2002 and (b) MY2000.43, both labelled at $t_{1}$. Protein spot 108, clearly visible near the bottom left-hand corner of $(a)$, is absent from $(b)$.

spots (labelled 201 to 210 in Fig. 4) are present at $t_{2}$ that are never seen at $t_{1}$, and a further seven spots (labelled 301 to 307 in Fig. 5) are seen at $t_{3}$ but not at $t_{2}$.

In addition to these 'new' spots, which represent proteins whose synthesis becomes detectable during sporulation, we have also observed proteins whose synthesis is 'switched off' during sporulation: for example the nine spots labelled 50 to 59 in Fig. 2 are present at $t_{0}$ but absent at $t_{1}$. Interestingly enough, four of the new spots that appear at $t_{1}$ subsequently stop being synthesized, three $\left(128,129\right.$ and 131) by $t_{2}$ and one (124) between $t_{2}$ and $t_{3}$. In addition to these, a further five 'old' spots (151 to 155 in Fig. 3) are present at $t_{1}$ but not at $t_{2}$, and four more (251 to 254 in Fig. 4) are present at $t_{2}$ but not at $t_{3}$. We have not detected any spots that disappear and subsequently reappear. 


\section{Effect of a spoOA mutation on the changes in pattern}

Strain MY2000.43 carries spo-43, a mutation in the spoOA locus. Mutations in this locus are the most pleiotropic, and the earliest, of all known spo mutations (Piggot \& Coote, 1976).

The pattern of protein synthesis in the mutant labelled at $t_{0}$ was indistinguishable from that in the wild-type. In cells labelled at $t_{1}$ or later, however, many differences from the wild-type were apparent (see, for example, Fig. 6). We intend to publish a full account of these later; our present concern is with the effect of spo-43 on the changes mentioned in the previous section.

Of the 35 proteins whose synthesis (so far as we can detect) starts between $t_{0}$ and $t_{1}$ ten (numbers 101, 108, 115, 118, 120,121, 126, 127, 128 and 129) appeared only in the wild-type. The remainder appeared in both the wild-type and the mutant (except that 103 and 113 were not always present in the mutant). Similarly, of the proteins that are first seen at $t_{2}$, six (numbers 202, $203,204,205,207$ and 208) appeared only in the wild-type, and of those that are first seen at $t_{3}$, six $(301,302,303,304,305$ and 307$)$ were found only in the wild-type.

spo-43 also affects some but not all of the proteins whose synthesis ceases in the wild-type during the first $3 \mathrm{~h}$ of sporulation. Proteins 55, 57, 58 and 59 ceased to be synthesized between $t_{0}$ and $t_{1}$ both in the wild-type and in strain MY2000.43. On the other hand, proteins 51, 52, 53, 54 and 56 stopped being synthesized in the wild-type, but their synthesis continued in the mutant; and the same was true, later in the incubation, of the five proteins 151 to 155 and the four proteins 251 to 254 . However, protein 131 stopped being synthesized (between $t_{1}$ and $t_{2}$ ), and protein 124 stopped being synthesized (between $t_{2}$ and $t_{3}$ ), in both strains.

In summary, mutation spo-43 prevents the onset of synthesis of 22 out of 52 proteins, and also prevents the cessation of synthesis of 14 out of 20 proteins. Among the 22 proteins whose synthesis is prevented by spo-43 are two out of the four which, in the wild-type, are made at $t_{1}$ but not subsequently.

\section{DISCUSSION}

Our procedure for labelling cells and making and analysing extracts yields highly reproducible patterns of radioactive spots. Most of these spots are common to all of the fluorograms that we have examined, but about $10 \%$ of them are present in extracts made from wild-type cells labelled at certain times during sporulation but absent from cells labelled at $t_{0}$. It is important to keep in mind that the absence of a spot from a particular extract means only that the corresponding protein is not being labelled (or is being labelled so feebly as to escape detection) during the 5 min incubation with ${ }^{35}$ S $]$ methionine; it does not necessarily mean that the protein is itself absent from the cells.

The results show that the pattern of protein synthesis changes after wild-type $B$. subtilis is transferred from growth medium to resuspension medium. Many more of the changes occur between $t_{0}$ and $t_{1}$ than in either of the two subsequent hours, and many more of the changes are in the direction of starting the synthesis of new proteins than in stopping the synthesis of old ones. We presume that these changes fall into two classes: some are specific to the early stages of sporulation, and some are non-specific responses to starvation analogous to those that might occur in non-sporulating genera of bacteria. In an attempt to distinguish these two classes we did experiments with strain MY2000.43. This strain is isogenic with our wild-type except for the presence of a very early spo mutation, and we could detect no difference in the pattern of protein synthesis between the mutant and the wild-type when both were labelled at $t_{0}$. We therefore think it reasonable to conclude that any change in protein synthesis that occurs in wild-type cells when resuspended in sporulation medium but does not occur in the mutant is specifically connected with sporulation.

Table 1 summarizes the number of changes that occur in the wild-type during the three successive hourly intervals from $t_{0}$ and the number of these that are abolished by spo-43. (Other differences in protein pattern between the wild-type and the mutant will be described in a subsequent paper.) Whereas the total number of new spots appearing in the first hour is fivefold more than in the third hour ( 35 versus 7 ), the number whose appearance is prevented by spo- 43 is less than twofold more (10 versus 6). Thus, the results show that during each hour from $t_{0}$ to $t_{3}$, 


\section{Table 1. Summary of the changes in the protein spots}

Number of proteins whose synthesis starts Number of proteins whose synthesis ceases

\begin{tabular}{|c|c|c|c|c|c|c|}
\hline \multirow[b]{2}{*}{$\begin{array}{l}\text { Hour of } \\
\text { resuspension }\end{array}$} & \multicolumn{3}{|c|}{ Number of proteins whose synthesis starts } & \multicolumn{3}{|c|}{ Number of proteins whose synthesis ceases } \\
\hline & $\begin{array}{c}\text { Total } \\
\text { appearing } \\
\text { in the } \\
\text { wild-type }\end{array}$ & $\begin{array}{l}\text { Appearing } \\
\text { only in } \\
\text { the } \\
\text { wild-type }\end{array}$ & $\begin{array}{l}\text { Appearing } \\
\text { in the } \\
\text { mutant and } \\
\text { in the } \\
\text { wild-type }\end{array}$ & $\begin{array}{l}\text { Total } \\
\text { disappearing } \\
\text { from the } \\
\text { wild-type }\end{array}$ & $\begin{array}{l}\text { Disappearing } \\
\text { only from } \\
\text { the } \\
\text { wild-type }\end{array}$ & $\begin{array}{l}\text { Disappearing } \\
\text { from the } \\
\text { mutant and } \\
\text { from the } \\
\text { wild-type }\end{array}$ \\
\hline First & 35 & 10 & 25 & 9 & 5 & 4 \\
\hline Second & 10 & 6 & 4 & $6(+2)^{*}$ & 5 & 1 \\
\hline Third & 7 & 6 & 1 & 5 & 4 & 1 \\
\hline
\end{tabular}

* Number in parentheses refers to spots that appear at $t_{1}$ in the wild-type but which are absent from the mutant both at $t_{1}$ and subsequently.

about eight sporulation-specific proteins start to be synthesized that were not synthesized (or whose synthesis was undetectable) an hour previously; similarly at each hour four to five proteins stop being synthesized that were undergoing synthesis an hour earlier. Of particular interest are two proteins whose synthesis can be detected in the wild-type at $t_{1}$ but not at $t_{0}$, which stop being synthesized by $t_{2}$, and which never appear in the mutant.

What can we say about the changes that occur both in the wild-type and in the mutant? It would be tempting to conclude that all these are responses to starvation of a kind that are not specific to sporulation. Such a conclusion is particularly attractive in the light of the numbers in Table 1. These show that (contrary to the situation with the new proteins that are made only in the wild-type), the number of new proteins that are made in both the wild-type and the mutant falls abruptly after the first hour. Since it is well known that new sporulation-specific proteins continue to be made for several hours after resuspension (for review, see Mandelstam, 1976), one might well conclude that the proteins that are made in the mutant as well as in the wild-type are not sporulation-specific.

We believe, however, that this conclusion, although it is probably correct for most of the proteins made in the mutant, is not certain to be true of all of those that are synthesized in the first hour. The fact that spoOA is the earliest spo locus known does not mean that it is necessarily the first spo locus to be expressed. There might be a few sporulation-specific proteins whose biosynthesis begins soon after $t_{0}$ but is not blocked by spoOA mutations, and some of these might still be undergoing synthesis at $t_{1}$. A similar argument can be made about the proteins whose synthesis ceases during sporulation. There are some proteins that cease to be synthesized in the wild-type but not in the mutant, and in these cases the 'switching off' is specifically related to sporulation: but it is conceivable that the same may also be true of some of those that cease to be synthesized both in the mutant and in the wild-type.

Even if we count just those proteins that appear only in the wild-type and not in the mutant, the present method has detected 22 sporulation-specific proteins that are newly synthesized in the first three hours of sporulation. We can make an extremely rough calculation to show how many sporulation-specific proteins one would expect to be newly synthesized during this period. A statistical study has shown that the total number of spo loci is probably of the order of 50 (Hranueli et al., 1974), and such genetic results as are available imply that each locus contains one or two genes (Lloyd-Jones, 1976; Dancer \& Mandelstam, 1981; Yudkin \& Turley, 1981; Hirochika et al., 1981). Thus, the total number of spo genes is perhaps of the order of 80 , and it now seems as if most of these are expressed by $t_{3}$ (Dion \& Mandelstam, 1980; Jenkinson et al., 1980 ). On the other hand, some spoO gene products are synthesized during vegetative growth (Hirochika et al., 1981) and would not be detected as 'new' proteins by our criteria. We may conclude, therefore, that the number of sporulation-specific proteins that are newly synthesized between $t_{0}$ and $t_{3}$ is likely to be in the region of 60 .

Although this calculation is obviously extremely imprecise, it suggests that we have detected a third to a half of the sporulation-specific proteins being made during the first three hours of 
resuspension. It is perhaps significant that the total number of proteins that we see on the gels is about half the number detected by O'Farrell (1975) in E. coli. If the basis of the calculation above is approximately correct, the implication is that, by improving the sensitivity of the technique, we should be able to uncover most of the changes in protein synthesis that occur in sporulation.

Since two-dimensional electrophoresis does not rely on catalytic activity, it should be capable of detecting not only enzymes but also structural and regulatory proteins. It may help, too, in identifying the primary products of genes that have been known only from the gross phenotypic consequences of their mutations. The method will also be valuable for determining, more precisely than has so far been possible, the time at which a mutation is expressed. We are now studying some spo mutants to see whether the point at which they appear to be blocked by the usual biochemical and morphological criteria coincides with the point at which their pattern of protein synthesis begins to be aberrant.

We are most grateful to A. Friedmann, Y. Milner and I. Ohad for valuable discussions and for the loan of equipment. M.D.Y. is indebted to M. Rigbi for graciously providing space in his laboratory. This work was supported by a grant from the Thyssen Foundation to A.K., and was done during M.D.Y.'s tenure of a Fellowship under the Royal Society-Israel Academy Programme.

\section{REFERENCES}

BonNer, W. M. \& LASKey, R. A. (1974). A film detection method for tritium-labelled proteins and nucleic acids in polyacrylamide gels. European Journal of Biochemistry 46, 83-88.

DANCER, B. N. \& MANDElstam, J. (1981). Complementation of sporulation mutations in fused protoplastis of Bacillus subtilis. Journal of General Microbiology 123, 17-26.

Dion, P. \& Mandelstam, J. (1980). Germination properties as marker events characterizing late stages of Bacillus subtilis spore formation. Journal of Bacteriology 141, 786-792.

EPHRATI-ElizUR, E. (1968). Spontaneous transformation in Bacillus subtilis. Genetical Research 11, 83-96.

Hirochika, H., Kobayashi, Y., Kawamura, F. \& SAITo, H. (1981). Cloning of sporulation gene spoOB of Bacillus subtilis and its genetic and biochemical analysis. Journal of Bacteriology 146, 494-505.

Hranueli, D., Piggot, P. J. \& Mandelstam, J. (1974). Statistical estimate of the total number of operons specific for Bacillus subtilis sporulation. Journal of Bacteriology 119, 684-690.

Jenkinson, H. F., KAY, D. \& MANDElstam, J. (1980). Temporal dissociation of late events in Bacillus subtilis sporulation from expression of genes that determine them. Journal of Bacteriology 141, 793-805.

LiNN, T. \& Losick, R. (1976). The program of protein synthesis during sporulation in Bacillus subtilis. Cell 8, 103-114.

LLOYD-JONES, G. (1976). Genetics and biochemistry of bacterial sporulation. M.Sc. thesis, University of Oxford.

MANDELSTAM, J. (1976). Bacterial sporulation: a problem in the biochemistry and genetics of a primitive developmental system. Proceedings of the Royal Society B193, 89-106.

O'FARRELL, P. H. (1975). High resolution two-dimensional electrophoresis of proteins. Journal of Biological Chemistry 250, 4007-4021.

Piggot, P. J. \& Coote, J. G. (1976). Genetic aspects of bacterial endospore formation. Bacteriological Reviews 40, 908-962.

Prestidge, L., Gage, V. \& Spizizen, J. (1971). Protease activities during the course of sporulation in Bacillus subtilis. Journal of Bacteriology 107, 81 5-823.

Sterlini, J, M. \& Mandelstam, J. (1969). Commitment to sporulation in Bacillus subtilis and its relationship to development of actinomycin resistance. Biochemical Journal 113, 29-37.

YudKIN, M. D. \& TURLEY, L. (1981). Mapping of six mutations in the spoIIA locus of Bacillus subtilis and studies of their response to a nonsense suppressor. Journal of General Microbiology 124, 255-261. 